\title{
Levels of Heavy Metals in the Soil: Effects of Season, Agronomic Practice and Soil Geology
}

\author{
Monsurat Temitope Osobamiro' ${ }^{1}$ Gregrory Olufemi Adewuyi ${ }^{2}$ \\ ${ }^{1}$ Department of Chemical Sciences, Olabisi Onabanjo University, Ago-Iwoye, Nigeria \\ ${ }^{2}$ Department of Chemistry, University of Ibadan, Ibadan, Nigeria \\ Email: topebamiro@gmail.com
}

Received 26 October 2015; accepted 23 November 2015; published 26 November 2015

Copyright (C) 2015 by authors and Scientific Research Publishing Inc.

This work is licensed under the Creative Commons Attribution International License (CC BY). http://creativecommons.org/licenses/by/4.0/

(c) (i) Open Access

\begin{abstract}
Heavy metals status of agricultural soils should be monitored in order to prevent soil-plant pollution. This study evaluates the effect of season, agronomic practice and soil mineral composition on the levels of some heavy metals ( $\mathrm{Pb}, \mathrm{Mn}, \mathrm{Ni}, \mathrm{Fe}$, and $\mathrm{Zn}$ ) in the arable and oil palm soils of three Farm Settlements in Ogun-State Southwest, Nigeria. Soil samples were collected in two consecutive seasons between 2010 and 2012 and digestion was carried out using Standard Wet Acid Digestion method. Total heavy metals in the digest were determined using Flame Atomic Absorption Spectrophotometer (FAAS). The total levels of heavy metals (in $\mathrm{mg} / \mathrm{kg}$ ) found in the sampled soils were as follows: in the rainy season Mn (28.4 - 34.2), Fe (1599.7 - 2013.2), Pb (11.0 - 16.9), Zn (100.5 112.9) and Ni (11.3 - 13.8) and in the dry season Mn (32.1 - 40.1), Fe (1701.4 - 2455.5), Pb (13.0 18.7), Zn (105.7 - 110.4) and $\mathrm{Ni}(15.5$ - 16.3). Levels of the heavy metals found in the sampled soils were significantly lower $(p<0.05)$ than their permissible levels in agricultural soils. Although the levels of heavy metals determined in dry season were higher than those of the rainy season, the only seasonal difference was that of $F e$ in Sawonjo soil significant at $p=0.05$. The level of heavy metals in oil palm soils was significantly higher than the level in arable soils $(p<0.05)$. At present, pollution level of heavy metals in the sampled soils is low and poses no environmental risk, yet, they have to be regularly monitored before they bio-accumulate into toxic. Government should therefore set up soil monitoring agency and provide irrigation facilities to encourage dry season farming.
\end{abstract}

\section{Keywords}

Heavy Metal, Farm-Settlement, Agro-Ecosystem, Seasonal Variation, Soil Mineral 


\section{Introduction}

Heavy metals pollution in agricultural soils has become one of the global challenges facing food production and the sustainability of life. It has been reported that pollution of agricultural soils can be as a result of long-term farming or excessive use of agrochemicals [1]. Heavy metals (though, some are useful to plants and animals when present in only traces amounts as micronutrients) become dangerous when they persist and accumulate to the level of toxicity [2] [3]. Heavy metals such as $\mathrm{Cu}, \mathrm{Fe}, \mathrm{Zn}, \mathrm{Mn}$, Co and Se, essentially aid metabolism but at a higher concentration can adversely affect human health and her growth, and sometimes, they can result in death. Other heavy metals, such as $\mathrm{Pb}, \mathrm{Cd}$, and $\mathrm{Hg}$, do not play any essential role in plant growth, but rather adversely affect its growth [4].

In Nigeria, one of the cardinal programmes of the present government is food security and improved agriculture, a drive purported to take the country into the league of the first twenty economies of the world by 2020 . Hence, the country is currently witnessing a rapid transformation in her agricultural programmes and policies. But, if the agricultural soils are not well monitored, particularly, in terms of heavy metals level in the soil, there is no way the country would be able to accomplish such a laudable goal by 2020 . Unless the country takes into cognizance a soil management practice which is environmental friendly, it will be difficult to effectively address the problematic state of her agricultural soils, particularly, the level of heavy metals contained therein. Therefore, heavy metals in the soil need to be effectively monitored before an irreparable damage is done to farmlands.

A significant proportion of agricultural soil in developing countries like Nigeria, especially for those located in the rural areas, has not been adequately monitored or investigated to check the levels of heavy metals contained in the soil [5]. Worse still, there is little or no information about the level of heavy metals contained in the soil from season to season. This study therefore investigated some of the intensively used Farm Settlements in Ago-Iwoye, Ajegunle and Sawonjo of Ogun State and assessed the seasonal variation of heavy metals $(\mathrm{Pb}, \mathrm{Mn}$, $\mathrm{Ni}, \mathrm{Fe}$, and $\mathrm{Zn}$ ) as they affect soil pollution in both arable and oil palm soils.

\section{Materials and Methods}

\subsection{Description of the Study Site}

The study area is Ogun-State, south-western Nigeria, located within latitude $6^{\circ} \mathrm{N}$ and $8^{\circ} \mathrm{N}$ and longitude $2.5^{\circ} \mathrm{E}$ and $5^{\circ} \mathrm{E}$. This state is predominantly tropical secondary rain forest area with a wooded savannah in the northwest [6]. The area had a bimodal rainfall, with peaks between June-July and September-October. The sampling area comprised three farm settlements located in the major geographical zones in the state, that is, Ago-Iwoye, Ajegunle and Sawonjo.

\subsection{Sampling}

Samples were collected in both dry season (December and February) and rainy seasons (June and September), between December 2010 and September 2012. Sampling was done using soil auger and hand trowel, plastic spatula and tape rule.

Randomized Experimental Block Design with two replications was used for this work. Stratified random sampling was used for sampling in which each farmland (arable and oil palm) was divided into plots of size 100 $\mathrm{m} \times 100 \mathrm{~m}$. Five plots were selected and a control site was also selected based on the diversity of farm settlement. Five samples were collected from each plot per sampling-month at $0-15 \mathrm{~cm}$ soil depth (i.e. top soil) with Geographical Position System (GPS) to record the coordinates. Figure 1 shows the map of the study area with sampling points. 600 soil samples including control samples were collected in well labelled polythene bags and transported to the laboratory where they were air dried for two weeks at ambient temperature. They were then sieved to $2 \mathrm{~mm}$ for general soil physiochemical and heavy metals analysis. Two final replicate samples from the dried bulk were selected using coning and quartering method [7].

\subsection{Laboratory Analysis}

Soil pH was measured in a 1:2 soil/water suspension. Soil Organic Carbon (OC) was determined by wet oxidation method of Walkley and Black [8]. Cation Exchange Capacity (CEC) was determined by extraction with 1 $\mathrm{M} \mathrm{NH}_{4} \mathrm{OAc}(\mathrm{pH}$ 7.0) [9]. The hydrometer method [10] was used for the particle size distribution. $10 \mathrm{~mL}$ of a 


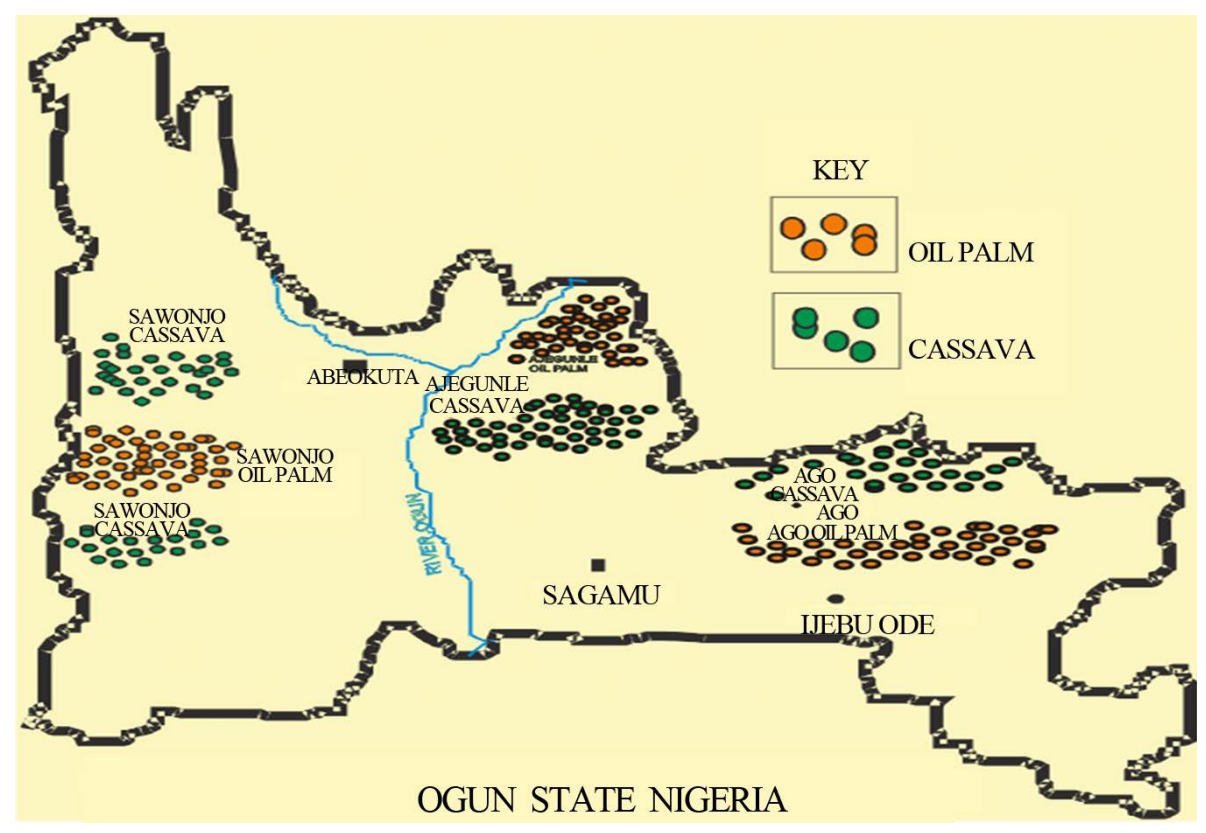

Figure 1. Map of Ogun-State showing the sampling points in the three farm settlements.

very efficient acid mixture Nitric $\left(\mathrm{HNO}_{3}\right)$, Sulphuric $\left(\mathrm{H}_{2} \mathrm{SO}_{4}\right)$ and Perchloric $\left(\mathrm{HCIO}_{4}\right)$ acid in a volume ratio of 3:1:1 was used to sufficiently complete the dissolution of $1 \mathrm{~g}$ of each sample [11] [12]. Metal determinations in the filtrate of the digested soil samples were performed using Buck Model 205 flame Atomic Absorption Spectrophotometer. Calibrations curves were performed with standard solutions prepared in aliquots of sample blanks

\subsection{Quality Assurance Protocol}

Quality assurance and quality control protocol include; procurement of analytical grade chemicals Nitric $\left(\mathrm{HNO}_{3}\right.$ from Sigma Aldrich), Sulphuric $\left(\mathrm{H}_{2} \mathrm{SO}_{4}\right)$ and Perchloric $\left(\mathrm{HCIO}_{4}\right)$, recovery studies (spiking), and blanks determination. Glass wares and plastic bottles were taken through the standard analytical processes before use.

\section{Results and Discussion}

\subsection{Variation in Soil Properties}

Variation in general soil properties between the arable and permanent agro-ecosystems: There are variations in some of the soil properties determined in the soils of the two agro-ecosystems but only variation among organic carbon, organic matter, nitrogen and $\mathrm{C} / \mathrm{N}$ ratio are significant at $\mathrm{p}=0.05$ (Table 1 ).

On the other hand, phosphorus\%, silt\% and clay\% are higher (even though insignificant) under the arable agro-ecosystem than under the oil palm agro-ecosystem.

The mean $\mathrm{pH}$ values of all the soil samples analysed indicated that all are slightly acidic (as reported by ref [6] for soils in Ogun State). Some of the nutrients required for plant growth may be available in the $\mathrm{pH}$ range of the studied soils, and significantly, heavy metals may also be available particularly those that can lead to plant contamination and toxicity if they exceed nutritional requirement of plants. Low $\mathrm{pH}$ can also affect the proper functioning of micro-organism such as nitrifying bacteria thereby reducing the amount of nitrogen in available form which is required for plant growth [13]. At low $\mathrm{pH}$, free metal cations and protonated anions are mobile, since $\mathrm{H}^{+}$ions can displace most other cations at negatively charged soil surfaces [14]. Variations in soil properties under similar agro-ecological zones may be as a result of parent materials [15], landscape position, land use and cultural practices [16]. Little variation observed in some of the soil properties (organic carbon and nitrogen) of sampled soils from the two agro-ecosystems may be as a result of differences in the plant soil requirements and root type. 
Table 1. Mean value of physicochemical properties of soil in the three farm settlements.

\begin{tabular}{|c|c|c|c|c|c|}
\hline & & Mean \pm S.D & Sig. (2-tailed) & Is Mean Diff sig.? & Range \\
\hline \multirow{2}{*}{$\mathrm{pH}$} & Arable & $6.05 \pm 0.31$ & 0.15 & Not sig & $5.50-6.50$ \\
\hline & Oil Palm & $6.18 \pm 0.34$ & 0.15 & & $5.40-6.80$ \\
\hline \multirow{2}{*}{ Organic carbon $(\mathrm{g} / \mathrm{kg})$} & Arable & $15.9 \pm 5.1$ & 0.00 & Sig & $9.80-26.5$ \\
\hline & Oil Palm & $21.4 \pm 6.9$ & 0.00 & & $12.6-36.1$ \\
\hline \multirow{2}{*}{ Organic matter $(\mathrm{g} / \mathrm{kg})$} & Arable & $27.6 \pm 9.0$ & 0.00 & Sig & $16.9-45.6$ \\
\hline & Oil Palm & $37.5 \pm 12.3$ & 0.00 & & $22.7-63.7$ \\
\hline \multirow{2}{*}{ Phosphorus (mg/kg) } & Arable & $19.2 \pm 5.9$ & 0.08 & Not sig & $8.66-29.3$ \\
\hline & Oil Palm & $16.3 \pm 4.9$ & 0.08 & & $3.54-23.9$ \\
\hline \multirow{2}{*}{ Nitrogen (g/kg) } & Arable & $1.12 \pm 0.41$ & 0.00 & Sig & $0.68-2.20$ \\
\hline & Oil Palm & $1.74 \pm 0.64$ & 0.00 & & $1.06-3.60$ \\
\hline \multirow{2}{*}{ CEC (cmol/kg) } & Arable & $6.27 \pm 3.31$ & 0.56 & Not sig & $2.69-11.1$ \\
\hline & Oil Palm & $5.73 \pm 3.03$ & 0.56 & & $2.56-12.0$ \\
\hline \multirow{2}{*}{ Exchangeable acidity } & Arable & $0.23 \pm 0.06$ & 0.28 & Not sig & $0.15-0.31$ \\
\hline & Oil Palm & $0.26 \pm 0.12$ & 0.29 & & $0.10-0.60$ \\
\hline \multirow{2}{*}{$\%$ Sand } & Arable & $84.1 \pm 4.7$ & 0.39 & Not sig & $76.4-89.4$ \\
\hline & Oil Palm & $85.4 \pm 5.3$ & 0.04 & & $72.4-92.6$ \\
\hline \multirow{2}{*}{ \% Clay } & Arable & $7.83 \pm 2.07$ & 0.87 & Not sig & $5.40-11.0$ \\
\hline & Oil Palm & $7.73 \pm 1.76$ & 0.87 & & $4.80-11.0$ \\
\hline \multirow{2}{*}{$\%$ Silt } & Arable & $8.08 \pm 3.38$ & 0.27 & Not sig & $4.00-14.4$ \\
\hline & Oil Palm & $6.90 \pm 3.83$ & 0.27 & & $1.40-16.6$ \\
\hline \multirow{2}{*}{$\mathrm{C} / \mathrm{N}$} & Arable & 14.2 & 0.02 & Sig & $14.4-12.0$ \\
\hline & Oil Palm & 12.3 & 0.02 & & $7.50-17.7$ \\
\hline
\end{tabular}

\subsection{Variation in the Levels of Heavy Metals}

a) Seasonal Variation in the Levels of the Heavy Metals in the Soils of the Three Farm Settlements

Seasonal variation was found in the levels of heavy metals extracted from each of the farm settlements in dry and rainy seasons. Levels of most of the heavy metals extracted in dry season were significantly higher than that of rainy season (at $p=0.05$ ) with oil palm soil samples having the highest (Table 2 and Table 3). Changes in the environment often have a greater effect on micronutrient and availability of heavy metals than on macronutrient nutrition of plants. Annual precipitation above $1000 \mathrm{~mm} /$ year has been said to have observable effect on the depletion and enrichment trends of trace elements in soils [17]. The average precipitation in the studied area is about $1150 \mathrm{~mm}$. High precipitation, leaching, erosion and plant uptake may account for the reduction in heavy metal levels in rainy season observed in the results of heavy metals from the three farm settlements. Higher levels of heavy metals recorded in dry seasons in the three locations may favour dry season farming where irrigation facilities are available, provided the levels are still within the permissible or required level that can support plant growth and this may account, in part, for the commonly observed good performance of crops during dry season irrigation farming.

b) Variation in the Levels of Heavy Metals in the Arable and Permanent Oil Palm Plantation

The result of the levels of heavy metals in arable and oil palm soils indicates that variation exist in these levels in the two agro-ecosystem. The mean level of these metals differs significantly $(\mathrm{p}<0.05)$ between the arable and the oil palm plantations (Table 4). Levels of heavy metals found in oil palm soil are significantly higher than their levels in the arable soils. 
Table 2. Seasonal variation in the mean levels of heavy metals in the oil palm soils of the three farm settlements.

\begin{tabular}{|c|c|c|c|c|c|c|c|}
\hline & \multirow[b]{2}{*}{ Season } & \multicolumn{2}{|c|}{ Sawonjo } & \multicolumn{2}{|c|}{ Ago-Iwoye } & \multicolumn{2}{|c|}{ Ajegunle } \\
\hline & & Mean \pm Std. Dev & Sig. & Mean \pm Std. Dev & Sig. & Mean \pm Std. Dev & Sig. \\
\hline \multirow{2}{*}{ Mn } & Rainy & $42.2 \pm 2.0$ & 0.01 & $44.2 \pm 0.8$ & 0.00 & $43.1 \pm 0.9$ & 0.00 \\
\hline & Dry & $44.9 \pm 0.3$ & & $40.3 \pm 0.4$ & & $47.6 \pm 0.9$ & \\
\hline \multirow{2}{*}{$\mathrm{Fe}$} & Rainy & $2262 \pm 27$ & 0.00 & $1907 \pm 96$ & 0.00 & $1689 \pm 90$ & 0.00 \\
\hline & Dry & $3030 \pm 90$ & & $2007 \pm 35$ & & $1711 \pm 10$ & \\
\hline \multirow{2}{*}{$\mathrm{Pb}$} & Rainy & $29.7 \pm 0.7$ & 0.00 & $15.9 \pm 0.3$ & 0.00 & $22.0 \pm 0.7$ & 0.03 \\
\hline & Dry & $32.5 \pm 0.8$ & & $20.0 \pm 0.8$ & & $23.1 \pm 0.8$ & \\
\hline \multirow{2}{*}{ Zn } & Rainy & $138 \pm 11$ & 0.00 & $134 \pm 32$ & 0.50 & $141 \pm 13$ & 0.00 \\
\hline & Dry & $141.1 \pm 0.7$ & & $143 \pm 29$ & & $144 \pm 9$ & \\
\hline \multirow{2}{*}{$\mathrm{Ni}$} & Rainy & $15.9 \pm 0.5$ & 0.00 & $17.0 \pm 0.8$ & 0.00 & $18.7 \pm 0.9$ & 0.00 \\
\hline & Dry & $22.9 \pm 0.7$ & & $20.4 \pm 0.8$ & & $21.4 \pm 0.6$ & \\
\hline
\end{tabular}

Table 3. Seasonal variation in the mean levels of heavy metals in the arable soils of the three farm settlements.

\begin{tabular}{|c|c|c|c|c|c|c|c|}
\hline & \multicolumn{3}{|c|}{ Sawonjo } & \multicolumn{2}{|c|}{ Ago-Iwoye } & \multicolumn{2}{|c|}{ Ajegunle } \\
\hline & Season & Mean \pm Std. Dev & Sig. & Mean \pm Std. Dev & Sig. & Mean \pm Std. Dev & Sig. \\
\hline \multirow[t]{2}{*}{ Mn } & Rainy & $14.6 \pm 1.0$ & 0.00 & $24.1 \pm 1.0$ & 0.00 & $21.0 \pm 1.0$ & 0.00 \\
\hline & Dry & $19.4 \pm 1.4$ & & $31.7 \pm 1.2$ & & $32.6 \pm 0.8$ & \\
\hline \multirow[t]{2}{*}{$\mathrm{Fe}$} & Rainy & $1763 \pm 17$ & 0.00 & $1291 \pm 12$ & 0.00 & $2110 \pm 90$ & 0.00 \\
\hline & Dry & $1881 \pm 38$ & & $1395 \pm 14$ & & $2409 \pm 10$ & \\
\hline \multirow[t]{2}{*}{$\mathrm{Pb}$} & Rainy & $4.10 \pm 0.90$ & 0.16 & $6.0 \pm 0.8$ & 0.97 & $6.7 \pm 0.7$ & 0.00 \\
\hline & Dry & $5.00 \pm 1.20$ & & $6.0 \pm 1.1$ & & $9.0 \pm 1.0$ & \\
\hline \multirow[t]{2}{*}{ Zn } & Rainy & $87.5 \pm 1.3$ & 0.00 & $67.0 \pm 1.1$ & 0.00 & $68.0 \pm 1.0$ & 0.21 \\
\hline & Dry & $79.6 \pm 1.0$ & & $71.0 \pm 0.8$ & & $67.3 \pm 0.7$ & \\
\hline \multirow[t]{2}{*}{$\mathrm{Ni}$} & Rainy & $6.6 \pm 0.8$ & 0.02 & $10.7 \pm 0.9$ & 0.02 & $8.7 \pm 0.9$ & 0.07 \\
\hline & Dry & $8.0 \pm 1.0$ & & $12.1 \pm 0.9$ & & $9.6 \pm 0.7$ & \\
\hline
\end{tabular}

Table 4. Differences in mean values of the heavy metals in soils under the two different agro-ecosystems in the three farm settlements.

\begin{tabular}{|c|c|c|c|c|c|}
\hline & & Mean \pm S.D $(\mathrm{mg} / \mathrm{kg})$ & Range (mg/kg) & Sig. (2-tailed) & Is Mean Diff sig.? \\
\hline \multirow{2}{*}{ Mn } & Oil palm & $43.7 \pm 2.5$ & 39.8 - 48.7 & 0.00 & Significant \\
\hline & Arable & $23.9 \pm 6.7$ & $13.3-33.6$ & 0.00 & \\
\hline \multirow{2}{*}{$\mathrm{Fe}$} & Oil palm & $2101 \pm 464$ & $1687-3044$ & 0.00 & Significant \\
\hline & Arable & $1808 \pm 392$ & $1289-2411$ & 0.00 & \\
\hline \multirow{2}{*}{$\mathrm{Pb}$} & Oil palm & $23.9 \pm 5.7$ & $15.5-33.1$ & 0.00 & Significant \\
\hline & Arable & $6.14 \pm 1.81$ & $2.97-10.2$ & 0.00 & \\
\hline \multirow{2}{*}{$\mathrm{Zn}$} & Oil palm & $140 \pm 12$ & $120-199$ & 0.00 & Significant \\
\hline & Arable & $73.4 \pm 7.8$ & $65.3-89.1$ & 0.00 & \\
\hline \multirow{2}{*}{$\mathrm{Ni}$} & Oil palm & $19.4 \pm 2.5$ & 15.2 - 23.6 & 0.00 & \\
\hline & Arable & $9.29 \pm 1.98$ & $5.56-13.0$ & 0.00 & Significant \\
\hline
\end{tabular}


Higher levels of these heavy metals found in oil palm soil in the three farm settlements, may possibly be because crop plantations are often grown with high level of agrochemical (pesticides, herbicides and inorganic fertilizers) which have been reported to contain significant amount of heavy metals [1].

The rate of nutrient and heavy metals decline under annual (arable) cropping systems are often much higher than that under perennial crops because loss through leaching and soil erosion is smaller in perennial crops plantation than under annual crops [18]. Also, Tree crops grow the whole year and plant nutrients are recycled by their deep roots, whereas in annual cropping there may be periods when there is no crop to cover the soil and prevent wind erosion. More frequent harvesting from an arable soil causes faster translocation of its cations away, compared to the perennial oil palm soil. The roots of plantation crops are more fibrous holding soil together, thereby reducing leaching and erosion.

Nearly all of the components of the photosynthetic apparatus are influenced by these heavy metals, including chlorophyll and carotenoid content, chloroplast membrane structure, light-harvesting and oxygen-evolving complexes, photosystems and constituents of the photosynthetic electron transport chain [19]. Mn is involved in the structure of chloroplast and in the biochemical events of photosynthesis. Fe-S proteins have functions in metabolic processes, such as photosynthesis, $\mathrm{SO}_{4}$ and $\mathrm{SO}_{3}$ reduction, respiration, the tricarboxylic acid cycle, and $\mathrm{N}_{2}$ fixation. Zn-containing enzyme (carbonic anhydrase) localized in the cytoplasm and chloroplasts facilitate the transfer of $\mathrm{CO}_{2} / \mathrm{HCO}_{3}^{-}$for photosynthetic $\mathrm{CO}_{2}$ fixation [20]. Nickel accumulates readily in plant leaves and seeds [21], thus, having a high potential to enter the food chain. Photosyntates in the form of vegetable crops containing most of these heavy metals are harvested and translocated via markets to consumers, thereby depleting the levels of these heavy metals on the arable farm.

Though, Lead is not considered to be an essential element for plant growth and development, moreover it inhibits growth, reduces photosynthesis, interferes with cell division and respiration, reduces water absorption and transpiration, accelerates abscission or defoliation and pigmentation, and reduces chlorophyll and ATP synthesis [22]. Higher concentrations of $\mathrm{Pb}$ have been reported to be likely found in leafy vegetables (e.g., lettuce) and on the surface of root crops (e.g., carrots) [23] via which it can be more easily lost with harvested material from arable soil.

In contrast, what are harvested in the palm plantations are mostly the palm nuts which do not contain the photosynthetic plasmids, and therefore may not involve translocation of these metals from the farm to the consumers. The palm fronts that drop are largely recycled back into the soil on the farm.

Table 5 showed the comparison of levels of heavy metals analysed with sampling location and type of land use. No significant difference exist in the levels of $\mathrm{Ni}$ and $\mathrm{Mn}$ based on sampling location and Land use ( $\mathrm{p} \leq$ 0.05) that is; levels of $\mathrm{Mn}$ and $\mathrm{Ni}$ found in the arable and oil palm soils of the three farm settlements are statistically similar whereas, levels of $\mathrm{Fe}, \mathrm{Pb}$, and $\mathrm{Zn}$ in the soil samples of the three farm settlements were different based on sampling location and land use. Difference in the levels of these heavy metals may be from natural source, anthropogenic or other.

The total levels (in mg/kg) of Mn (30.0 - 48.6), Pb (8.25 - 22.5), Fe (1405.6 - 2243.9), Zn (86.7 - 166.2) and $\mathrm{Ni}(13.5$ - 25.9) and (Tables 2-4) were all within acceptable range. Therefore, they have not yet risen to the level of pollution. The levels of all the metals analysed in the soils were significantly lower $(p<0.05)$ than the permissible level. This is true for the level in both the rainy and dry seasons, and in all the locations. The permissible level of $\mathrm{Mn}, \mathrm{Pb}$ and $\mathrm{Ni}$ in the soil is between 100 - 300, 15 - 25 and 15 - $30 \mathrm{mg} / \mathrm{kg}$ respectively [24]. Therefore they may pose no environmental risk despite long period of farming.

\subsection{Geological Composition of the Soils}

Variation found in the levels of the heavy metals determined in the soils from the two agro-ecosystems in the three farm settlements may not only due to anthropogenic source but may be due to the difference in the geological make-up of these soils. Higher level of Fe recorded in all the samples analysed may be as a result of high Fe mineralogical content of these soils that is typical of tropical soil. Abundance of iron oxide has been reported to be present in Ferruginous soil found in Sawonjo area in Ogun State [6]. This is evident in the mineralogical result of Sawonjo arable and oil palm soils containing high percentage of iron oxide (Table 6). Ago-Iwoye and Ajegunle soils have been classified under Ferralitic soil which is rich in ferro-manganese mineral [6]. This is evident in the mineralogical analysis of Ago Iwoye and Ajegunle arable soils and oil palm soil of Ago-Iwoye, indicating the presence of iron minerals such as; hematite, siderite, pyrite and lepidocrocite. 
Table 5. Comparison of heavy metal levels based on sampling location and land use tests of between-subjects effects.

\begin{tabular}{ccccccc}
\hline Source & Dependent Variable & Type III Sum of Squares & df & Mean Square & F & Sig. \\
\hline & Manganese & 175 & 2 & 87.3 & 2.21 & 0.121 \\
sampling_loc * & Iron & $3,574,378$ & 2 & $1,787,189$ & 26.7 & 0.000 \\
land_use & Lead & 510 & 2 & 255 & 20.6 & 0.000 \\
& Zinc & 3765 & 2 & 1882 & 4.64 & 0.015 \\
& Nickel & 5.17 & 2 & 2.58 & 0.181 & 0.835 \\
\hline
\end{tabular}

Table 6. Summary of percentage mineralogical composition of soils from the three farm settlements.

\begin{tabular}{|c|c|c|c|c|c|c|c|}
\hline Sampling Site & $\begin{array}{l}\text { Type of } \\
\text { Mineral }\end{array}$ & Minerals Absorbed & $\begin{array}{l}\% \text { of the } \\
\text { Mineral }\end{array}$ & Sampling Site & $\begin{array}{l}\text { Type of } \\
\text { Mineral }\end{array}$ & Minerals Absorbed & $\begin{array}{l}\% \text { of the } \\
\text { Mineral }\end{array}$ \\
\hline \multirow{4}{*}{$\begin{array}{c}\text { Ago-Iwoye } \\
\text { Arable }\end{array}$} & Clay Mineral & Corensite and Kaolinite & 61.3 & \multirow{3}{*}{$\begin{array}{l}\text { Ago Iwoye } \\
\text { Oil palm }\end{array}$} & $\begin{array}{l}\text { Carbonate } \\
\text { Minerals }\end{array}$ & $\begin{array}{l}\text { Aragonite and } \\
\text { Dolomite }\end{array}$ & 84.2 \\
\hline & \multirow[t]{2}{*}{ Iron Mineral } & \multirow[t]{2}{*}{ Heamatite } & \multirow[t]{2}{*}{38.5} & & Iron Mineral & Siderite & 7.89 \\
\hline & & & & & $\begin{array}{l}\text { Non Clay } \\
\text { Minerals }\end{array}$ & Quartz & 7.89 \\
\hline & Clay Mineral & $\begin{array}{l}\text { Montmorillonite and } \\
\text { Kaolinite }\end{array}$ & 23.5 & \multirow{3}{*}{$\begin{array}{l}\text { Ajegunle Oil } \\
\text { palm }\end{array}$} & Clay Mineral & $\begin{array}{l}\text { Montmorillonite and } \\
\text { Smectite }\end{array}$ & 27.4 \\
\hline \multirow[t]{3}{*}{$\begin{array}{l}\text { Ajegunle } \\
\text { Arable }\end{array}$} & Iron Mineral & $\begin{array}{l}\text { Siderite, Pyrite and } \\
\text { Heametite }\end{array}$ & 62.3 & & Iron Mineral & Lepidogocite & 13.7 \\
\hline & $\begin{array}{l}\text { Non Clay } \\
\text { Minerals }\end{array}$ & Calcite & 14.3 & & $\begin{array}{l}\text { Carbonate } \\
\text { Minerals }\end{array}$ & Dolomite & 43.8 \\
\hline & Clay Mineral & Montmorrilonite & 10.81 & \multirow{3}{*}{$\begin{array}{l}\text { Sawonjo Oil } \\
\text { palm }\end{array}$} & Clay Mineral & $\begin{array}{l}\text { Illite, Chorite and } \\
\text { Smectite }\end{array}$ & 68.7 \\
\hline \multirow[t]{2}{*}{$\begin{array}{l}\text { Sawonjo } \\
\text { Arable }\end{array}$} & Iron Mineral & Siderite and Pyrite & 75.7 & & Iron Mineral & Heamatite & 6.96 \\
\hline & Others & & 13.4 & & $\begin{array}{c}\text { Carbonate } \\
\text { Mineral }\end{array}$ & $\begin{array}{l}\text { Aragonite and } \\
\text { Dolomite }\end{array}$ & 15.7 \\
\hline
\end{tabular}

High levels of carbonate minerals (aragonite and dolomite) found in oil palm soils of the three farm settlements may also in part, account for the higher levels heavy metals recorded in the oil palm soils of the three farm settlements. Dolomite (limestone mineral), a soil conditional that increase soil alkalinity and reduced soil acidity was indicated in the oil palm plantation soils of all the three farm settlements. This is evident in the pH value in the oil palm plantation soils of all the three farm settlements (Table 1).

\subsection{Correlation Studies of Heavy Metals}

All metals analysed showed a significantly strong positive correlation with one another at $0.05 \%$ (Table 7). The positive correlation between these metals showed that there was association or interaction among these metals in the study area, and on the other hand, they might have similar sources of input, According to Miller and Miller, [25], a strong correlation between two variables or metals may be an occurrence of strong dependence of both variables on the same causal factor probably due to their common derivation from the stores in the basement complex [26].

\section{Conclusion}

This study examines the effect of season and cropping system on heavy metals ( $\mathrm{Mn}, \mathrm{Fe}, \mathrm{Pb}, \mathrm{Zn}$ and $\mathrm{Ni}$ ) pollution level in the farm settlements soil. Although, the pollution level in the studied sites is low, it poses no environmental risk yet; the agricultural soils need to be monitored against any incursion of toxicity. The study establishes that seasons, agronomic practise, and soil geological make-up do affect the level of heavy metals (Mn, Fe, $\mathrm{Pb}, \mathrm{Zn}$ and $\mathrm{Ni}$ ) in soils. It was also discovered that heavy metals’ pollution load in oil plantation soils was found to be higher than that of the arable soils and the metal bio-magnification is high in the soil-plant system. In view 
Table 7. Correlation of heavy metals.

\begin{tabular}{cccccc}
\hline & $\mathrm{Mn}$ & $\mathrm{Fe}$ & $\mathrm{Pb}$ & $\mathrm{Zn}$ & $\mathrm{Ni}$ \\
\hline $\mathrm{Mn}$ & 1 & $0.58^{* *}$ & $0.67^{* *}$ & $0.59^{* *}$ & $0.73^{* *}$ \\
$\mathrm{Fe}$ & $0.58^{* *}$ & 1 & $0.74^{* *}$ & $0.75^{* *}$ & $0.61^{* *}$ \\
$\mathrm{~Pb}$ & $0.67^{* *}$ & $0.74^{* *}$ & 1 & $0.81^{* *}$ & $0.82^{* *}$ \\
$\mathrm{Zn}$ & $0.58^{* *}$ & $0.75^{* *}$ & $0.81^{* *}$ & 1 & $0.69^{* *}$ \\
$\mathrm{Ni}$ & $0.74^{* *}$ & $0.61^{* *}$ & $0.82^{* *}$ & $0.69^{* *}$ & 1 \\
\hline
\end{tabular}

*Correlation is significant at the 0.05 level (2-tailed). **Correlation is significant at the 0.01 level (2-tailed).

of the higher heavy metal contents in the dry season soil, government should provide facilities for, and encourage dry season irrigation farming at designated places in order to take advantage of the biochemical facilitation of the heavy metals.

\section{References}

[1] Micó, C., Recatalá, L., Peris, M. and Sánchez, J. (2006) Assessing Heavy Metal Sources in Agricultural Soils of a European Mediterranean Area by Multivariate Analysis. Chemosphere, 65, 863-872. http://dx.doi.org/10.1016/j.chemosphere.2006.03.016

[2] Tuzen, M. (2003) Determination of Heavy Metals in Fish Samples of the Middame Lakes Black Sea (Turkey) by Graphite Furnace Atomic Absorption Spectophotometry. Food Chemistry, 80, 119-123. http://dx.doi.org/10.1016/S0308-8146(02)00264-9

[3] Adriano, D.C. (2001) Trace Elements in Terrestrial Environments: Biogeochemistry, Bioavailability and Risks of Metals. 2nd Edition, Springer, New York, 860. http://dx.doi.org/10.1007/978-0-387-21510-5

[4] Kubilay, N., Nickovic, S., Moulin, C. and Dulac, F. (2000) An Illustration of the Transport and Deposition of Mineral Dust onto the Eastern Mediterranean. Atmospheric Environment, 34, 1293-1303. http://dx.doi.org/10.1016/S1352-2310(99)00179-X

[5] Oyekunle, J.A.O., Ogunfowokan, A.O., Torto, N. and Akanni, M.S. (2011) Levels of Heavy Metals in Agricultural Soils of Oke-Osun Farm Settlement Osogbo, Nigeria. Journal of International Environmental Application \& Science, 6, 483-496.

[6] Gbadegesin, S.A. (1992) Soils. In: Onakomaya, S.O., Oyesiku, K. and Jegede, J., Eds., Ogun State in Maps, Res. Charles Publication, Ibadan, 207.

[7] Fifield, F.W. and Kealey, D. (1990) Principles and Practice of Analytical Chemistry. 3rd Edition, Chapman and Hall, Blackie Academic and Professional, London, 469-490.

[8] Walkley, A. and Black, I.A. (1934) An Examination of Degtjareff Method for Determining Soil Organic Matter and a Proposed Modification of the Chromic Acid Titration Method. Soil Science, 37, 29-38. http://dx.doi.org/10.1097/00010694-193401000-00003

[9] Soil Survey Laboratory Staff (1992) Soil Survey Laboratory Methods Manual. Soil Survey Investigations Report No. 42, USDA-SCS, Washington DC.

[10] Bouyoucos, G.J. (1962) Hydrometer Method Improved for Making Particle Size Analysis of Soils. Agronomy Journal, 53, 464-465. http://dx.doi.org/10.2134/agronj1962.00021962005400050028x

[11] Barman, S.C., Sahu, R.K., Bhargava, S.K. and Chatterjee, C. (2000) Distribution of Heavy Metals in Wheat, Mustard and Weed Grown in Fields Irrigated with Industrial Effluents. Bulletin of Environmental Contamination and Toxicology, 64, 489-496. http://dx.doi.org/10.1007/s001280000030

[12] Twyman, R.M. (2005) Sample Dissolution for Elemental Analysis: Wet Digestion. In: Worsfold, P., Townshend, A. and Poole, C., Eds., Encyclopedia of Analytical Science, 2nd Edition, Volume 8, Elsevier Science, London, 146- 153.

[13] Sylvia, D.M., Fuhmann, P.G., Hartel, P.G. and Zuberer, D.A., Eds. (1998) Principles and Application of Soil Microbiology. Prentice Hall, Upper Saddle River.

[14] Keepax, R.E., Moyes, L.N. and Livens, F.R. (2011) Speciation of Heavy Metals and Radioisotopes. In: Aleksandar, S., Ed., Environmental and Ecological Chemistry Volume II, Encyclopedia of Life Support Systems (EOLSS), 165-199.

[15] Esu, I.E. (1999) Fundamentals of Pedology. Stirling-Horden Publishers (Nig.) Ltd., Ibadan, 136.

[16] FAO, Food and Agricultural Organization (1990) Guidelines for Soil Profile Description. 3rd Edition, FAO, Rome, 70. 
[17] Teutsch, N., Erel, Y., Halicz, L. and Chadwick, O.A. (1999) The Influence of Rainfall on Metal Concentration and Behavior in the Soil. Geochimica et Cosmochimica Acta, 63, 3499-3511. http://dx.doi.org/10.1016/S0016-7037(99)00152-0

[18] Hartemink, A.E. (2003) Soil Fertility Decline in the Tropics—With Case Studies on Plantations. ISRIC-CABI Publishing, Wallingford. http://dx.doi.org/10.1079/9780851996707.0000

[19] Barcelo, J. and Poschenrieder, C. (2004) Structural and Ultra Structural Changes in Heavy Metal Exposed Plants. In: Prasad, M.N.V., Ed., Heavy Metal Stress in Plants, 3rd Edition, Springer, Berlin, 223-248. http://dx.doi.org/10.1007/978-3-662-07743-6_9

[20] Dimou, M., Paunescu, A., Aivalakis, G., Flemetakis, E. and Katinakis, P. (2009) Co-Localization of Carbonic Anhydrase and Phosphoenol-Pyruvate Carboxylase and Localization of Pyruvate Kinase in Roots and Hypocotyls of Etiolated Glycine max Seedlings. International Journal of Molecular Sciences, 10, 2896-2910. http://dx.doi.org/10.3390/ijms10072896

[21] Welch, R.M. and Cary, E.E. (1975) Concentration of Chromium, Nickel and Vanadium in Plant Materials. Journal of Agricultural and Food Chemistry, 23, 479-482. http://dx.doi.org/10.1021/jf60199a017

[22] Miller, G.S., Begonia, G.B., Begonia, M.F.T. and Ntoni, J. (2008) Bioavailability and Uptake of Lead by Coffee Weed (Sesbania exaltata raf.). International Journal of Environmental Research and Public Health, 5, 436-440. http://dx.doi.org/10.3390/ijerph5050436

[23] Raymond, A.W. and Okieimen, F.E. (2011) Heavy Metals in Contaminated Soils: A Review of Sources, Chemistry, Risks and Best Available Strategies for Remediation International Scholarly Research Network Ecology, Tolerance in Plants. Biochimie, 88, 1707-1719.

[24] US Environmental Protection Agency (1997) Test Methods of Evaluation for Solid Waste. USEPA S/W 846 UEPA, Washington DC.

[25] Miller, J.N. and Miller, J.C. (2000) Statistics and Chemometrics for Analytical Chemistry. 4th Edition, Pearson Education Limited, Essex, 271.

[26] Olutona, G.O., Olapeju, G.A. and Emmanuel, A.A. (2012) A Study of Chemical Speciation of Metals in Aquatic Bottom Sediment of Aiba Reservoir, Iwo, Nigeria. African Journal of Environmental Science and Technology, 6, 312-321. 